\title{
How does servitisation affect supply chain circularity? - A systematic literature review
}

\section{Abstract}

Purpose - The aim of this review is to test the link between servitisation and circular economy (CE) by synthesising the effect of product-service systems (PSS) on supply chain circularity.

Design/methodology/approach - Following a systematic literature review methodology, the study identified 67 studies and synthesised them using content analysis.

Findings - A conceptual model is developed illustrating how PSS business models impact supply chain circularity through increased product longevity, closure of resource loops, and resource efficiency. It also identifies six contextual factors affecting the implementation of supply chain circularity including: 1) Economic attractiveness of supply chain circularity; 2) Firm sustainability strategy; 3) Policy and societal environment; 4) Product category; 5) Supply chain relationships; 6) Technology.

Research limitations/implications - The conceptual model proposes that supply chain circularity increases with servitisation. It also proposes that the main circularity effect stems from increased product longevity, followed by closed resource loops, and finally resource efficiency. The model is deduced from the literature by using secondary data.

Practical implications - The review provides practitioners with a framework to increase supply chain circularity through PSS business models. It also gives insight into the various contextual factors that may affect how a manufacturer's servitisation strategy contributes to supply chain circularity.

Originality/value - This review contributes to the understanding of the relationship between servitisation and supply chain circularity by synthesising the different effects that exist. Moreover, it creates new knowledge by identifying a range of contextual factors affecting the relationship between PSS and supply chain circularity.

Keywords Circular Economy, Product-service system, Supply chain management, Servitisation, Systematic literature review

Paper type Literature Review 


\section{Introduction}

The circular economy (CE) concept advocates that business models should change from selling to renting, leasing, or sharing technical products (Ellen MacArthur Foundation, 2014; Lacy and Rutqvist, 2015). These business models are considered a key enabler to the development of circular supply chains (De Angelis et al., 2018; Batista et al., 2018; Ellen MacArthur Foundation, 2014; Lacy and Rutqvist, 2015). Circular supply chains are defined as 'the coordinated forward and reverse supply chains via purposeful business ecosystem integration for value creation from product/ services, byproducts and useful waste flows through prolonged life cycles that improve the economic, social, and environmental sustainability of organisations' (Batista et al., 2018, p.446). They are closely related to reverse logistics (Fleischmann et al., 2001) and closed-loop supply chains (Guide et al., 2003).

The interest in manufacturers moving away from selling products to providing combinations of goods and services emerged in the late 1980s (Vandermerwe and Rada, 1988; Wise and Baumgartner, 1999). The so-called servitisation phenomenon was a response to competitive pressures, as manufacturers sought differentiation opportunities by offering services along the entire product lifecycle (Oliva and Kallenberg, 2003). The most well-known example is the Rolls-Royce's 'power-bythe-hour' scheme. Instead of selling jet engines, Rolls-Royce carries out installation, maintenance, repair, and modernisation services while charging customers only for using the engine (Gebauer et al., 2013). Other examples are: Caterpillar's equipment management services, that include condition monitoring, preventive maintenance, and repair or Xerox' printer fleet management services (Baines and Lightfoot, 2013a). Even though most servitisation cases stem from business-to-business contexts, examples also emerge from consumer markets, such as car- and bike-sharing or washing machines (Gebauer et al., 2017; Vezzoli et al., 2015).

Servitised offerings are often referred to as product-service systems (PSS), which are defined as 'tangible products and intangible services designed and combined so that they jointly are capable of fulfilling specific customer needs' (Tukker, 2004). Other terms to describe such offerings are basic, intermediate, or advanced services (Baines and Lightfoot, 2013b), outcome-based contracts (Ng et al., 2009), performance-based contracts (Hypko et al., 2010), or solutions (Brady et al., 2005). PSS offerings are usually typified along a product-service continuum, in which the focus of the offering changes from being mainly product-based towards being more service-based (Tukker, 2004). There are three main PSS categories:

- Product-oriented: The main focus is still on selling products. The offering is enhanced by product-related services, such as maintenance or insurance contracts (Gaiardelli et al., 2014; Tukker, 2004).

- Use-oriented: The focus is on providing functionality or access, for example, through leasing, renting, or sharing instead of selling products (Gaiardelli et al., 2014; Tukker, 2004). 
Running Head: Effect of servitisation on supply chain circularity

- Result-oriented: In these services, a function or pre-determined result is provided and not a product (e.g. pay-per-unit). The provider is completely free to decide how results are delivered (Gaiardelli et al., 2014; Tukker, 2004).

To date, the link between PSS business models and the development of circular supply chains is mainly theoretical. It is based on the assumption that when companies provide services instead of selling products, they are incentivised to optimise their resource utilisation, for example by improving efficiency, increasing product lifetime, or reducing the overall number of products in use (Mont et al., 2006; Reim et al., 2015; Tukker, 2004; Vezzoli et al., 2015). Use- and result-oriented PSS are considered to have the highest potential for $\mathrm{CE}$ because the manufacturer retains product ownership and thereby also responsibility for the product over its life cycle (Reim et al., 2015). As a result, the manufacturer has economic incentives to reduce disposal costs or costs of manufacturing new products as well as to recover value at end-of-life, for example through reuse or remanufacturing (Vezzoli et al., 2015).

Supply chains play a critical role in enabling firms' competitiveness (Hassini, 2008). Similarly, increasing supply chain circularity has been shown to reduce costs and generate new revenue streams. In 2017, Hewlett Packard refurbished and remarketed 1.27 million units of hardware, thereby creating new sales opportunities (Strandberg, 2017). JLG industries, a manufacturer of material handling equipment, reduced its equipment costs by $35 \%$ by refurbishing old cherry pickers (Ellen MacArthur Foundation, 2017a). Through remanufacturing, Caterpillar is able to get the same performance of components at $50-60 \%$ of the cost (Ellen MacArthur Foundation, 2017b). Even though the case for increased net value creation from circular supply chains is quite straightforward, manufacturers may be reluctant to implement PSS business models due to business risks associated with product ownership retention (Linder and Williander, 2015). Moreover, it is questionable how important the environmental concerns for PSS providers are, since servitisation is predominantly driven by strategic and commercial interests (Baines et al., 2009a; Oliva and Kallenberg, 2003). As a result, selling PSS instead of products may not always lead to higher circularity (Kjaer et al., 2018; Tukker, 2004).

The aim of this review is to test the assumed link between servitisation and CE by synthesising the effect of PSS on supply chain circularity (SCC). It aims to answer three review questions: 1) What is SCC? 2) How do PSS business models affect SCC? 3) What contextual factors affect the implementation of SCC? The paper adopts a systematic literature (SLR) methodology to identify and review 67 articles from the $\mathrm{CE}$ and PSS/servitisation fields. This review presents the first attempt to bridge the gap between theory and practice of SCC, by reviewing only empirical cases of PSS business model implementation. This helps validate the theoretical claims made about this relationship (Tukker, 2004). It also provides new knowledge by identifying and synthesising the contextual factors that can affect SCC implementation in PSS. The practical rationale for the study stems from the observation 
that the business case for adopting SCC in practice is not always as straightforward as suggested by the literature (Linder and Williander, 2015).

\section{Research Method}

This study adopts a SLR method (Tranfield et al., 2003) to select, map, and assess existing studies on CE and PSS. Compared to a critical literature review, SLR provides a more rigorous and transparent review process that allows for explanatory or interpretive findings (Denyer and Tranfield, 2009). Using such an approach can reduce bias and increase the legitimacy of the data analysis, thereby leading to reliable results (Becheikh et al., 2006). To ensure the transparency and replicability of this study, a series of steps were followed (Denyer and Tranfield, 2009) and presented in a similar way to Pilbeam et al. (2012): 1) planning, 2) searching, 3) screening, 4) extraction and synthesis, and 5) reporting. The search and selection processes are summarised in Figure 1.

\section{Planning}

In advance to this study, the authors carried out a scoping study as suggested by Tranfield et al. (2003). Based on the results of this scoping study, the research team and a guidance committee consisting of other academic experts in the field defined the research scope, questions, and inclusion/exclusion criteria to answer the aforementioned review questions.

\section{Searching}

\section{[INSERT TABLE 1 HERE]}

The keywords used in the literature search emerged from the scoping study (see Table 1). They were classified into search strings by using Boolean 'OR' operators, namely, supply chain management, CE, and PSS. To answer the first question ('What is SCC?'), SS1 and SS2 were combined through a Boolean 'AND' operator. The second question ('How do PSS business models affect SCC?') and the third question ('What contextual factors affect the implementation of supply chain circularity?'), were answered by combining all three strings. These search strings were then used to search two bibliographic (Scopus and Web of Science) and two content-based databases (ABI/Proquest and Ebsco). A total of 3,034 articles were identified and alerts were set up in the databases to help identify new publications.

\section{Screening}

[INSERT FIGURE 1 HERE] 
Running Head: Effect of servitisation on supply chain circularity

The paper selection process is described in Figure 1. 3,034 search results were exported from Scopus, Web of Science, ABI/Proquest and Ebsco to the reference management software Mendeley. Following the removal of 559 duplicates, 2,475 articles remained. The first screen of the articles was based on the article title and abstract against pre-determined inclusion (and exclusion) criteria (see Table 2).

\section{[INSERT TABLE 2 HERE]}

After rejecting 2,274 articles, 201 articles remained, which were then reviewed in a rigorous fulltext screening process against the same inclusion and exclusion criteria. During this screening process, the references of relevant articles were reviewed (snowballing) to identify other potentially relevant articles. The snowballing process identified an additional 10 papers. Following the full-text screening, 78 articles remained. The selected articles were subject to a quality appraisal process that covered the theory robustness, methodology, findings, and contribution (Pittaway et al., 2004). The articles were scored on scale of zero to three in each category. To be included, an article required a score of at least six in total. Eleven articles were rejected in this step leaving 67 articles, which qualify for review.

\section{Extraction and synthesis}

There are different approaches to data extraction and synthesis in SLRs. This review is based on heterogeneous qualitative and quantitative data. As a result, it is not suitable to use aggregative synthesis methods (Rousseau et al., 2008). In addition, an integrative approach was also excluded, since the review questions do not focus on exploring when interventions are likely to be appropriate (Rousseau et al., 2008). Instead, a mix of interpretive and explanatory approaches was used (Rousseau et al., 2008). In these methods, descriptive data and exemplars are extracted from studies to create explanations (Denyer et al., 2008). Content analysis is used as an extraction and synthesis method, since it can provide detailed assessments of descriptive and content criteria and also extend the perspective beyond single studies (Gold et al., 2010; Seuring and Müller, 2008).

In the first step of content analysis, papers were classified based on descriptive dimensions. This included the distribution across time, the employed research methodology, geographic context, industry setting, PSS type, and the journal the paper was published in. These categories were selected based on the standard practice for literature reviews (Seuring and Müller, 2008), as well as the inclusion and exclusion criteria of the study. In addition, analytic categories for the supply chain processes and the contextual factors affecting SCC were developed from the reviewed papers by means of generalisation (Seuring and Müller, 2008). One of the weaknesses of content analysis is that it relies on the researcher to judge how a paper is to be comprehended (Seuring and Müller, 2008). To account for this, the first author regularly discussed findings and coding matters with the other authors and 
resolved any disagreements through discussion. The dimensions and categories were iteratively revised during the analysis process.

\section{Descriptive Analysis}

This section presents the descriptive analysis of the literature review. The papers were classified in three categories: CE, PSS and circular PSS, where both themes overlapped. The CE and circular PSS papers answered the first review question, all papers answered the second and third review question. Figure 2 depicts the distribution the 67 reviewed papers.

\section{[INSERT FIGURE 2 HERE]}

Figure 2 shows that between 2005 and 2013, the publications exclusively focused on PSS and servitisation. In 2014, publications on CE slowly started to emerge, with the number of publications rising sharply between 2017-2018. Indeed, there was a particular increase in 2018 of those papers addressing both CE and PSS. This shows that the link between circular economy and the $\mathrm{PSS} /$ servitisation literature emerged only very recently.

The selected papers were categorised and analysed in regard to methodology, geographic context, industry setting, PSS type and journal (see Table 3). The methodologies were categorised based on the study types provided by Habib et al. (2015). The selected articles were divided across non-empirical papers (21) and empirical papers (46). In the non-empirical papers, the dominant type were literature reviews (12) and conceptual papers (8), while one was classified as mathematical. The majority of these papers focused on CE and circular supply chains (De Angelis et al., 2018; Batista et al., 2018). The empirical papers were predominantly case studies (42) compared to four papers based on surveys. Of the case studies, 39 focused on PSS of which 9 focused more specifically on circular PSS implementation. The dominance of case study methodologies underscores that this research area is in a nascent stage and still exploring the manifestation of this phenomenon in its real-life context.

\section{[INSERT TABLE 3 HERE]}

The non-empirical papers were not classified according geographic context, since they did not provide any specifications in this category. Almost all empirical papers focused on cases from European countries (40), especially from the United Kingdom (17) or Sweden (7), and only few exceptions from other contexts, such as Brazil (3) or China (1). The empirical papers were mainly from industries related to manufacturing, such as capital equipment, defence, or household appliances. Nevertheless, a growing number of publications focused on lower value product industries, such as textiles (Corvellec and Stål, 2017; Pal, 2016). The 39 empirical PSS papers were also differentiated based on the type of PSS. This total number exceeds 39 since some papers employed multiple case studies of different PSS types. There were 14 cases of product-oriented PSS, 12 cases of use-oriented 
PSS and 24 cases of result-oriented PSS indicating the high level of interest that PSS/ servitisation scholars have in these. The analysis also reveals that the discussion around supply chain and CE has primarily taken place in journals, such as the Journal of Cleaner Production, Production Planning \& Control, or Sustainability. The PSS and servitisation literature, however, is focused primarily on the International Journal of Operations \& Production Management, Industrial Marketing Management and the International Journal of Production Economics.

\section{Thematic Analysis}

This section presents the thematic findings of the review. In the first part, the CE literature was reviewed to identify relevant circular supply chain aims, indicators, and practices. In the second part, empirical PSS papers were reviewed to identify circular supply chain practices. In the final part of this analysis, contextual factors for the implementation of supply chain circularity were deduced from the CE and PSS literature. The main purpose of the review is to develop a conceptual model of SCC in PSS business models. The final framework is presented in Figure 3.

\subsection{Supply Chain Circularity (SCC)}

This section focuses on identifying relevant aims, performance measures, and practices of supply chain circularity (see Table 4).

\section{[INSERT TABLE 4 HERE]}

Circular supply chains focus on the creating value from prolonging product, component, and material life cycles through coordinated forward and reverse supply chains (Batista et al., 2018; Lieder and Rashid, 2016). They aim to close resource loops through recycling or remanufacturing, extend the lifetime of products through design changes or repairs, and increase resource efficiency by using fewer resources over the entire product life-cycle (Geissdoerfer et al., 2018; Yang et al., 2018).

\section{[INSERT TABLE 5 HERE]}

There are fifteen practices related to the principal aims of circular supply chains (see Table 5). These can be classified according to the supply chain processes along the product life cycle: material sourcing, design, production, distribution, use, and recovery. During the material sourcing and recovery processes, the practices are focused around the aim of closed resource loops. In the other processes, however, the practices are aimed at increasing resource efficiency and product longevity. 


\subsection{PSS business models and Supply Chain Circularity}

The review of Supply Chain Circularity in PSS business models focused on identifying circular supply chain practices implemented in the different PSS models: product-oriented, use-oriented, and result-oriented (see Table 6).

\section{[INSERT TABLE 6 HERE]}

The identified practices in the fourteen product-oriented PSS cases are almost all associated with the product longevity aim. Maintenance and repair occurred in all fourteen cases, while refurbishing was mentioned in four. In one case, however, the manufacturer of complex-engineered products decided against refurbishing components and instead fit new ones to boost sales (Lockett $e t$ al., 2011). The review also identified design practices associated with product longevity. In the case of soil compactors in Sweden, the company aimed to save costs by designing their products to increase the service intervals and to decrease the need for maintenance and remanufacturing (Sundin et al., 2009). In a capital equipment case, the manufacturer designed products for reliability and maintainability to ensure that the product had a low failure rate and that service activities could be conducted with ease and at low cost (Colen and Lambrecht, 2013). The dominance of practices associated with product longevity can be explained by the sample's focus around maintenance and technical support services. The review also identified some practices associated with resource loop closure. Two cases mentioned remanufacturing of products and components, which were implemented to facilitate spare-part provision and to rejuvenate the employed equipment (Colen and Lambrecht, 2013; Sundin et al., 2009). Recycling activities were only mentioned in cases of textile PSS, in which $\mathrm{H} \& \mathrm{M}$ and other companies implemented take-back schemes for clothes to either use them to produce lower value textiles or give them to charity (Corvellec and Stål, 2017; Pal, 2016). One case mentioned training activities to increase resource efficient product use (Chakkol et al., 2014).

Even though there are two cases less in use-oriented PSS (twelve) compared to product-oriented PSS, the total identified practices in this sample increased from 25 to 33. As with product-oriented PSS, the most widely mentioned activities were around product longevity, especially maintenance and repairs. In comparison to the previous sample, however, there were more design related practices (Fargnoli et al., 2018; Geissdoerfer et al., 2018; Sousa-Zomer et al., 2018a). In addition, the amount of closed resource loop practices increased. Recycling was identified in four cases, while remanufacturing occurred in five. In a bicycle case in Sweden, however, the manufacturer failed to expand its circular business model based on remanufacturing beyond the pilot phase due to the difficulty of forecasting demand for multiple product life-cycles (Linder and Williander, 2015). Cascades were also mentioned in the case of a water filtration equipment manufacturer in Brazil, where the firm created a spin-off, to sell by-products and waste resources to external partners (Sousa-Zomer et al., 2018a). This case had the most identified practices across all empirical PSS papers. For example, 
they also increased resource efficiency by reducing the use of chemicals in manufacturing processes, using energy-saving production equipment, systematically reducing waste in production, and incorporating environmental aspects into the logistics design (Sousa-Zomer et al., 2018a). Contrary to the other empirical papers in this review, it specifically focused on implementing circularity across the entire supply chain. This can be explained by the manufacturer's strong commitment to sustainability and CE. In one case, the manufacturer supported the customer in the resource efficient use of the product (Bressanelli et al., 2018).

The most practices were identified in result-oriented PSS (62), which was expected since these are the largest number of cases (24). Similar to the previous two PSS types, the vast majority of practices were around product longevity, especially maintenance and repairs. In some, products were also designed for disassembly and for longevity (Manninen et al., 2018; Sundin et al., 2009). Two practices that were not previously identified were design for modularity and customisation. This was expected, because result-oriented PSS are less defined and focused on solving specific business needs (Saccani et al., 2014). Even though customisation is expected to reduce resource use by preventing waste and overproduction (Kalmykova et al., 2018), Yang et al. (2018) note that product customisation made remanufacturing and recycling costlier, thereby presenting a potential trade-off between customisation and the closure of resource loops. There were also a number of practices identified with the closure of resource loops. In the case of a gas generator manufacturer in China providing services around industrial gases, the company was able to cascade by-product gases to other supply chains (Yang et al., 2018). According to them, this was only possible in result-oriented PSS, since the manufacturer was able to control the production processes and thereby also the by-products. This sample also identified the highest number of practices associated with operational efficiency in the use phase. This can be explained by the manufacturer having control over product use to deliver results or by implementing comprehensive risk and reward sharing schemes, which can help ensure a customer's efficient product use (Gebauer et al., 2017a; Smith et al., 2014).

Overall, the results in this section show that there is an increase in amount and type of circular supply chain practices identified as PSS business models move from product- to result-oriented. Overall, the increase in supply chain circularity can be explained by: 1) The manufacturer internalising operational risks, resulting in the need for higher product reliability and maintainability (Colen and Lambrecht, 2013; Reim et al., 2016); 2) Product ownership retention incentivising manufacturers to maximise value capture across the product life cycle (Gebauer et al., 2017; Yang et al., 2018); 3) Having more information and control regarding the quantity and quality of product flows compared to traditional sales business models (Sundin and Bras, 2005; Yang et al., 2018). 


\subsection{Contextual factors affecting supply chain circularity}

This section reviews the contextual factors that can influence the implementation of circular supply chain practices. Thirteen factors were identified through the content analysis of the CE and PSS papers. These factors were classified into six categories based on their nature and meaning (see Table 7).

\section{[INSERT TABLE 7 HERE]}

- The economic attractiveness of SCC practices can have a positive effect on supply chain circularity. For example, Toyota Material Handling Group in Sweden increased its revenues by selling remanufactured forklift trucks it previously used in its PSS (Sundin et al., 2009). In addition, designing products for longevity can help reduce maintenance costs (Colen and Lambrecht, 2013; Sundin et al., 2009). But economic aspects can also have a negative effect on supply chain circularity. In one PSS case of gas generators in China, the potential value from end-of-life recovery was too little compared to the costs due to the long product lifetime and high degree of customisation (Yang et al., 2018). Another potential negative effect on SCC can stem from the risk of cannibalising existing product or component sales (Lockett et al., 2011).

- The firm sustainability strategy can positively affect the implementation of circular supply chain practices. This manifested itself in the case of a use-oriented PSS of water filtration equipment in Brazil (Sousa-Zomer et al., 2018a). The manufacturer received multiple awards for its commitment to sustainability, which was exemplified by the implementation of circular practices across all supply chain processes.

- The policy and societal environment can negatively affect circularity through customer concerns over the quality of refurbished or remanufactured products (Lieder and Rashid, 2016) as well as through laws and regulations that stifle waste recovery and/or cross-sector collaboration (De Angelis et al., 2018; Govindan and Hasanagic, 2018). Laws and regulations can also positively influence SCC through tax benefits and/or recycling requirements (Brown and Bajada, 2018; Lieder and Rashid, 2016). In addition, a well-developed waste management sector can provide the necessary infrastructure to implement circular supply chain practices (Corvellec and Stål, 2017).

- The product category can have a positive effect on SCC. Remanufacturing, for example, is considered most beneficial when the product has a core that can be restored, the associated technology is relatively stable, it can be easily disassembled and restored, and has relatively high recoverable value (Andreu, cited in Sundin, Lindahl and Ijomah, 2009). Nevertheless, it can also have a negative effect if the materials are unsuitable for 
Running Head: Effect of servitisation on supply chain circularity

recycling, too complex or when the product is subject to fashion changes (Ghisellini et al., 2016; Linder and Williander, 2015).

- Supply chain relationships can have a positive effect on circularity through cross-sector collaboration and the implementation of cascading resource flows (De Angelis et al., 2018). In addition, supply chain integration can positively affect SCC by enabling information sharing and the alignment of actors towards desired circularity outcomes. This is exemplified by sharing of materials and information between manufacturer and customer to minimise product failure (Fargnoli et al., 2018; Smith et al., 2014). The review also identified a number of PSS cases studies, where misalignment across the supply chain and resistance to share information prevented suppliers from effectively supporting maintenance services (Finne and Holmström, 2013; Lockett et al., 2011).

- The use of digital technology, such as internet of things or tracking and monitoring, can have a positive effect on SCC by facilitating maintenance and repair activities as well as facilitating product design improvements or facilitating recovery

(Bressanelli et al., 2018; Spring and Araujo, 2017). 


\subsection{PSS and Supply Chain Circularity - A conceptual model}

Based on the literature review presented, a conceptual model is presented (see Figure 3).

\section{[INSERT FIGURE 3 HERE]}

The conceptual model posits that servitisation and the transition from a product-oriented to a result-oriented PSS increases SCC. The first aim of SCC is product longevity. In product-oriented PSS, maintenance practices help increase the durability of the products and reduce the failure rate (Colen and Lambrecht, 2013). In use-oriented PSS, the product longevity increases. Here, the manufacturer retains ownership and is thus incentivised to prolong the product lifecycle through repairs and maintenance (Bressanelli et al., 2018; Reim et al., 2015). Longevity is also increased by refurbishing and reselling products in secondary markets (Gebauer et al., 2017a). In result-oriented PSS, the longevity potential is the highest, because the manufacturer is responsible for the delivery of specific outcomes. This is exemplified by extensive predictive and preventive maintenance as well as faster fault diagnostics and rectification (Baines and Lightfoot, 2013b; Johnstone et al., 2009). This argument leads to the following proposition:

Proposition 1: Product longevity is the highest in result-oriented PSS followed by use-oriented PSS, which has a higher product longevity than product-oriented PSS.

The second aim of SCC is the closure of resource loops. In product-oriented PSS, the review identified practices around the remanufacturing or recycling of old components that were recovered in repair or maintenance activities (Colen and Lambrecht, 2013). In use-oriented PSS, the manufacturer retains product ownership and is incentivised to recover products, components, and materials to maximise profits (Yang et al., 2018). The potential for closed resource loops increases in result-oriented PSS because the manufacturer has more control over resource flows in the use phase (Yang et al., 2018). This argument leads to the following proposition:

Proposition 2: Closure of resource loops is the highest in result-oriented PSS followed by use-oriented PSS, which has a higher closure of resource loops than product-oriented PSS.

The third aim of SCC is resource efficiency. In product-oriented PSS, there is limited potential for increasing resource efficiency, since the PSS provider has no formal interaction or control on the customer's use of the product. In use-oriented PSS, the PSS provider retains ownership, monitors user behaviour and supports the customer in efficient and sustainable usage (Bressanelli et al., 2018). In result-oriented PSS, the potential for increasing resource efficiency is the highest. Here, the manufacturer can control how products are used and can find innovative and efficient ways to deliver results (Reim et al., 2015; Yang et al., 2018). In addition, these offerings are highly customised, which can potentially prevent waste and over-production (Kalmykova et al., 2018). This argument leads to the following proposition: 
Running Head: Effect of servitisation on supply chain circularity

Proposition 3: Resource efficiency is the highest in result-oriented PSS followed by use-oriented PSS, which has a higher resource efficiency than product-oriented PSS.

Finally, the review suggests that the strength of the application of the circular supply chain practices differs. This was determined by the number of practices that were identified in the empirical PSS papers (see Table 6). The dominance of product longevity can be explained by the strategic importance of product reliability and maintainability in the delivery of PSS business models, especially result-oriented PSS (Baines and Lightfoot, 2013b; Colen and Lambrecht, 2013). In comparison, there were significantly fewer identified practices around closed resource loops. Evidence of difficulties in implementing remanufacturing and recycling (Linder and Williander, 2015; Yang et al., 2018) support the notion that a PSS business model adoption is not a guarantee for increased circularity (Kjaer et al., 2018). This argument leads to the following proposition:

Proposition 4: The main effect of servitisation on SCC stems from increased product longevity, followed by closed resource loops, and finally resource efficiency.

This model also identifies a number of contextual factors that can influence the degree to which PSS affects SCC (see Table 7). These are represented by the up- and down- ward facing arrow on the right side of the model and are as follows: 1) Economic attractiveness of SCC; 2) Firm sustainability strategy; 3) Policy and societal environment; 4) Product category; 5) Supply chain relationships; 6) Technology. As mentioned in section 4.3, the contextual factors can influence the implementation of circular supply chain practices. This argument leads to the following proposition:

Proposition 5: Contextual factors can have positive or negative effects on the relationship between servitisation and SCC.

\section{Discussion and conclusion}

\subsection{Research synthesis}

The CE concept considers servitised business models around renting, leasing, and sharing as a core enabler of circular supply chains. When customers only pay for the service they receive and manufacturers retain product ownership, the manufacturer will aim to reduce the amount of resources used (Reim et al., 2015; Vezzoli et al., 2015). To the authors' knowledge, this is the first attempt to synthesise existing research on PSS implementation and its effect on supply chain circularity.

This study answers the first review question ('What is SCC?') by identifying and linking the principal aims of supply chain circularity - close resource loops, increase product longevity, increase resource efficiency - and their performance indicators with fifteen supply chain practices. This contributes to previous conceptualisations of circular supply chains (De Angelis et al., 2018; Batista et al., 2018), which focused predominantly on defining and delineating circular supply chains from other 
concepts found in literature, such as closed-loop supply chains. In addition, it contributes by providing an approach to assessing SCC, a need that was previously identified (Elia et al., 2017).

In regard to the second question ('How do PSS business models affect SCC?'), the review synthesises the effects of servitisation on SCC. The findings are translated into five propositions. They confirm previous claims that the supply chain circularity potential increases as manufacturers move from offering product-oriented to result-oriented PSS and retain product ownership (Tukker, 2004, 2015; Vezzoli et al., 2015). The fourth proposition is based on the finding that more practices are identified as business models move from product- to result-oriented PSS. The relative lack of practices associated with closed resource loops and resource efficiency support the notion that PSS business model adoption is not a guarantee for increased circularity (Kjaer et al., 2018).

This ties into the findings for the third review question ('What contextual factors affect the implementation of supply chain circularity?'). The review contributes new knowledge by identifying a range of contextual factors that can positively and negatively influence the implementation of SCC practices. These are: 1) Economic attractiveness of SCC circularity; 2) Firm sustainability strategy; 3) Policy and societal environment; 4) Product category; 5) Supply chain relationships; 6) Technology. These findings are expressed in the fifth proposition.

\subsection{Theoretical implications}

This review contains a plethora of theoretical implications. SCC introduces new supply chain aims and practices, resulting in the need to be harmonised with traditional measures and metrics used for efficient and effective supply chain management (Sambasivan et al., 2009). This also implies an extension in the evaluation of information systems around sustainability outcomes (Piotrowicz and Cuthbertson, 2009). The findings also demonstrate the potential of servitisation and PSS business models to contribute to SCC. Nevertheless, the scarcity of circular supply chain practices suggests that there is still potential for the SCC concept to guide upstream and downstream process and product innovation in servitised supply chains (Walters and Rainbird, 2007). The review also gives insights into the various contextual factors that may affect how a manufacturer's servitisation strategy contributes to SCC. In doing so, it begins to bridge a previously identified gap in the literature (Reim et al., 2015). One finding from the review is that an organisation's strategy and culture around sustainability can potentially affect SCC implementation (Sousa-Zomer et al., 2018a, 2018b). This ties into existing findings on the effect of organisational culture on supply chain strategy formulation and implementation (Roh et al., 2008). 
Running Head: Effect of servitisation on supply chain circularity

\subsection{Practical implications}

This review bridges the gap between theory and practice in two ways: Firstly, it provides comprehensive empirical evidence about the effect of servitisation and PSS implementation on SCC, thereby validating the theoretical claims made about this relationship. This study impacts upon society, because it highlights the need to move away from ownership- to access- or functionality-based business models in the transition to a more sustainable and circular economy. It helps inform policy-makers on the importance of facilitating the implementation of PSS business models for SCC. The study also provides practitioners with a framework to increase supply chain circularity through PSS business models. Secondly, the review also gives insight into the various contextual factors that may affect how a manufacturer's servitisation strategy contributes to SCC. This gives PSS providers a roadmap to implement new business models and to reduce the uncertainties related to their implementation (Linder and Williander, 2015). It also provides governments with insights into the circumstances required for SCC in PSS business models and can therefore help inform effective policy-making.

\subsection{Research limitations}

The study has a few limitations to be considered. Firstly, this study draws on a body of literature around circular PSS implementation, which is still nascent and currently emerging. At present, there are few empirical studies that focus specifically on the relationship between PSS and supply chain circularity. This has implications for the findings around the practices associated with the closure of resource loops and resource efficiency. One possible explanation for the relative lack of empirical evidence is that these practices are not directly related to the provision of service outcomes. Product longevity on the other hand helps ensure a product's functionality and is therefore critical to a successful service delivery. As a result, existing studies may have simply not focused on aspects related to resource loop closure and resource efficiency in servitisation and PSS business model implementation. Another possible explanation is that product longevity is easier to grasp and to assess than the closure of resource loops and resource efficiency. Secondly, the review focused on peer-reviewed articles written in English, thereby not considering outputs published in other languages.

\subsection{Recommendations for future research}

This review provides the following future research avenues:

- The present study developed a conceptual model of PSS SCC which needs to be tested and empirically validated, for example, through conducting case study research. 
Running Head: Effect of servitisation on supply chain circularity

- The effect of PSS business model implementation on SCC can vary based on contextual factors. Further research is recommended to examine these contextual factors and understand the extent of their impact.

- The majority of articles in this review employed qualitative research methods. More quantitative studies are needed to further evaluate the link between PSS business models and specific circularity practices.

- Finally, more studies are needed beyond the European context as most studies in this review were predominantly from Europe. 
Running Head: Effect of servitisation on supply chain circularity

\section{References}

De Angelis, R., Howard, M. and Miemczyk, J. (2018), "Supply Chain Management and the Circular Economy : towards the Circular Supply Chain”, Production Planning \& Control, 29(6), pp. 425-437. Baines, T.S. and Lightfoot, H. (2013a), Made to Serve: How Manufacturers can Compete Through Servitization and Product Service Systems. Chichester (UK): John Wiley \& Sons.

Baines, T.S. and Lightfoot, H. (2013b), "Servitization of the manufacturing firm - Exploring the operations practices and technologies that deliver advanced services", International Journal of Operations \& Production Management, 34(1), pp. 2-35.

Baines, T.S., Lightfoot, H., Benedettini, O. and Kay, J.M. (2009a), "The servitization of manufacturing: A review of literature and reflection on future challenges", Journal of Manufacturing Technology Management, 20(5), pp. 547-567.

Baines, T.S., Lightfoot, H., Peppard, J., Johnson, M., Tiwari, A., Shehab, E. and Swink, M. (2009b), "Towards an operations strategy for product-centric servitization", International Journal of Operations \& Production Management, 29(5), pp. 494-519.

Bastl, M., Johnson, M., Lightfoot, H. and Evans, S. (2012), "Buyer-supplier relationships in a servitized environment", International Journal of Operations \& Production Management, 32(6), pp. $650-675$.

Batista, L., Bourlakis, M., Smart, P. and Maull, R. (2018), "In Search of a Circular Supply Chain Archetype - A Content-Analysis Based Literature Review", Production Planning \& Control, 29(6), pp. $438-451$.

Batista, L., Davis-Poynter, S., Ng, I. and Maull, R. (2017), "Servitization through outcome-based contract - A systems perspective from the defence industry", International Journal of Production Economics, 192(October), pp. 133-143.

Becheikh, N., Landry, R. and Amara, N. (2006), "Lessons from innovation empirical studies in the manufacturing sector: A systematic review of the literature from 1993-2003”, Technovation, 26(5-6), pp. 644-664.

Bernon, M., Tjahjono, B. and Ripanti, E.F. (2018), “Aligning retail reverse logistics practice with circular economy values: an exploratory framework", Production Planning and Control, 29(6), pp. 483-497.

Brady, T., Davies, A. and Gann, D.M. (2005), "Creating value by delivering integrated solutions", International Journal of Project Management, 23(5), pp. 360-365. 
Brax, S.A. and Jonsson, K. (2009), "Developing integrated solution offerings for remote diagnostics: A comparative case study of two manufacturers", International Journal of Operations \& Production Management, 29(5), pp. 539-560.

Bressanelli, G., Adrodegari, F., Perona, M. and Saccani, N. (2018), "Exploring how usage-focused business models enable circular economy through digital technologies", Sustainability (Switzerland), 10(3), p. 639.

Brown, P.J. and Bajada, C. (2018), “An economic model of circular supply network dynamics: Toward an understanding of performance measurement in the context of multiple stakeholders", Business Strategy and the Environment, 27(5), pp. 643-655.

Chakkol, M., Johnson, M., Raja, J. and Raffoni, A. (2014), "From goods to solutions : how does the content of an offering affect network configuration?", International Journal of Physical Distribution \& Logistics Management, 44(172), pp. 132-154.

Colen, P.J. and Lambrecht, M.R. (2013), "Product service systems: exploring operational practices", The Service Industries Journal, 33(5), pp. 501-515.

Corvellec, H. and Stål, H.I. (2017), "Evidencing the waste effect of Product-Service Systems (PSSs)", Journal of Cleaner Production, 145, pp. 14-24.

Datta, P.P. and Roy, R. (2011), “Operations strategy for the effective delivery of integrated industrial product-service offerings", International Journal of Operations \& Production Management, 31(5), pp. 579-603.

Denyer, D. and Tranfield, D. (2009), "Producing a Systematic Review”, in The Sage Handbook of Organizational Research Methods. London: Sage Publications, pp. 671-689.

Denyer, D., Tranfield, D. and van Aken, J.E. (2008), "Developing Design Propositions through Research Synthesis", Organization Studies, 29(3), pp. 393-413.

Durugbo, C. (2013), “Competitive product-service systems: Lessons from a multicase study", International Journal of Production Research, 51(19), pp. 5671-5682.

Elia, V., Gnoni, M.G. and Tornese, F. (2017), "Measuring circular economy strategies through index methods: A critical analysis", Journal of Cleaner Production, 142, pp. 2741-2751.

Ellen MacArthur Foundation (2014), “Towards the Circular Economy (Volume 3): Accelerating the scale-up across global supply chains", available at:

https://www.ellenmacarthurfoundation.org/assets/downloads/publications/Towards-the-circulareconomy-volume-3.pdf (accessed 18 June 2017).

Ellen MacArthur Foundation (2017a), "JLG \& DLL: Financing the expansion of circular business models", available at: https://www.ellenmacarthurfoundation.org/case-studies/financing-the- 
Running Head: Effect of servitisation on supply chain circularity

expansion-of-circular-business-models (accessed 3 May 2019).

Ellen MacArthur Foundation (2017b), "Caterpillar: Design and business model considerations for heavy machinery remanufacturing", available at: https://www.ellenmacarthurfoundation.org/casestudies/design-and-business-model-considerations-for-heavy-machinery-remanufacturing (accessed 3 May 2019).

Fargnoli, M., Costantino, F., Di Gravio, G. and Tronci, M. (2018), "Product service-systems implementation: A customized framework to enhance sustainability and customer satisfaction”, Journal of Cleaner Production, 188, pp. 387-401.

Finne, M. and Holmström, J. (2013), “A manufacturer moving upstream : triadic collaboration for service delivery”, Supply Chain Management: An International Journal, 18(1), pp. 21-33.

Fleischmann, M., Beullens, P., Bloemhof-Ruwaard, J.M. and Wassenhove, L.N. Van (2001), “The impact of product recovery on logistics network design", Production and Operations Management, 10(2), pp. 156-173.

Franco, M.A. (2017), "Circular economy at the micro level: A dynamic view of incumbents' struggles and challenges in the textile industry", Journal of Cleaner Production, 168, pp. 833-845.

Franklin-Johnson, E., Figge, F. and Canning, L. (2016), "Resource duration as a managerial indicator for Circular Economy performance”, Journal of Cleaner Production, 133, pp. 589-598.

Gaiardelli, P., Resta, B., Martinez, V., Pinto, R. and Albores, P. (2014), “A classification model for product-service offerings", Journal of Cleaner Production, 66, pp. 507-519.

Gebauer, H., Haldimann, M. and Saul, C.J. (2017a), “Competing in business-to-business sectors through pay-per-use services", Journal of Service Management, 28(5), pp. 914-935.

Gebauer, H., Paiola, M. and Saccani, N. (2013), "Characterizing service networks for moving from products to solutions", Industrial Marketing Management, 42(1), pp. 31-46.

Gebauer, H., Saul, C.J., Haldimann, M. and Gustafsson, A. (2017b), “Organizational capabilities for pay-per-use services in product-oriented companies", International Journal of Production Economics, 192(October), pp. 157-168.

Geissdoerfer, M., Morioka, S.N., de Carvalho, M.M. and Evans, S. (2018), "Business models and supply chains for the circular economy”, Journal of Cleaner Production, 190, pp. 712-721.

Genovese, A., Acquaye, A.A., Figueroa, A. and Koh, S.C.L. (2017), "Sustainable supply chain management and the transition towards a circular economy: Evidence and some applications", Omega, 66, pp. 344-357.

Ghisellini, P., Cialani, C. and Ulgiati, S. (2016), “A review on circular economy: The expected transition to a balanced interplay of environmental and economic systems", Journal of Cleaner 
Production, 114, pp. 11-32.

Gold, S., Seuring, S. and Beske, P. (2010), "Sustainable supply chain management and interorganizational resources: A literature review", Corporate Social Responsibility and Environmental Management, 17(4), pp. 230-245.

Govindan, K. and Hasanagic, M. (2018), “A systematic review on drivers, barriers, and practices towards circular economy: a supply chain perspective", International Journal of Production Research, 56(1-2), pp. 278-311.

Guide, V.D.R., Harrison, T.P. and Wassenhove, L.N. Van (2003), “The challenge of closed-loop supply chains", Interfaces, 33(6), pp. 3-6.

Habib, F., Bastl, M. and Pilbeam, C. (2015), "Strategic responses to power dominance in buyersupplier relationships: A weaker actor's perspective", International Journal of Physical Distribution \& Logistics Management, 45(1/2), pp. 182-203.

Hassini, E. (2008), "Building competitive enterprises through supply chain management", Journal of Enterprise Information Management, 21(4), pp. 341-344.

Hypko, P., Tilebein, M. and Gleich, R. (2010), "Clarifying the concept of performance-based contracting in manufacturing industries", Journal of Service Management, 21(5), pp. 625-655. Johnson, M. and Mena, C. (2008), "Supply chain management for servitised products: A multiindustry case study", International Journal of Production Economics, 114(1), pp. 27-39.

Johnstone, S., Dainty, A. and Wilkinson, A. (2009), "Integrating products and services through life: an aerospace experience", International Journal of Operations \& Production Management, 29(5), pp. $520-538$.

Kalmykova, Y., Sadagopan, M. and Rosado, L. (2018), "Circular economy - From review of theories and practices to development of implementation tools", Resources, Conservation and Recycling, 135(August), pp. 190-201.

Kapletia, D. and Probert, D. (2010), "Migrating from products to solutions: An exploration of system support in the UK defense industry", Industrial Marketing Management, 39(4), pp. 582-592.

Kazancoglu, Y., Kazancoglu, I. and Sagnak, M. (2018), “A new holistic conceptual framework for green supply chain management performance assessment based on circular economy", Journal of Cleaner Production, 195, pp. 1282-1299.

Kirchherr, J., Reike, D. and Hekkert, M. (2017), “Conceptualizing the Circular Economy: An Analysis of 114 Definitions”, Resources, Conservation and Recycling, 127(September), pp. 221-232.

Kjaer, L.L., Pigosso, D.C.A., Niero, M., Bech, N.M. and Mcaloone, T.C. (2018), "Product/ServiceSystems for a Circular Economy: The Route to Decoupling Economic Growth from Resource 
Running Head: Effect of servitisation on supply chain circularity

Consumption?", Journal of Industrial Ecology, Forthcoming.

Kleemann, F.C. and Essig, M. (2013), “A providers' perspective on supplier relationships in performance-based contracting", Journal of Purchasing and Supply Management, 19(3), pp. 185-198. Koh, S.C.L., Gunasekaran, A., Morris, J., Obayi, R. and Ebrahimi, S.M. (2017), “Conceptualizing a circular framework of supply chain resource sustainability", International Journal of Operations and Production Management, 37(10), pp. 1520-1540.

Lacy, P. and Rutqvist, J. (2015), Waste to Wealth. New York: Palgrave Macmillan.

Lieder, M. and Rashid, A. (2016), “Towards circular economy implementation: A comprehensive review in context of manufacturing industry", Journal of Cleaner Production, 115, pp. 36-51.

Lindahl, M., Sundin, E. and Sakao, T. (2014), "Environmental and economic benefits of Integrated Product Service Offerings quantified with real business cases", Journal of Cleaner Production, 64, pp. 288-296.

Linder, M., Sarasini, S. and van Loon, P. (2017), “A Metric for Quantifying Product-Level Circularity", Journal of Industrial Ecology, 21(3), pp. 545-558.

Linder, M. and Williander, M. (2015), “Circular Business Model Innovation: Inherent Uncertainties", Business Strategy and the Environment, 26(2), pp. 182-196.

Liu, C.H., Chen, M.-C., Tu, Y.-H. and Wang, C.-C. (2014), “Constructing a sustainable service business model: An SD logic-based integrated product service system (IPSS)", International Journal of Physical Distribution \& Logistics Management, 44(1/2), pp. 80-97.

Lockett, H., Johnson, M., Evans, S. and Bastl, M. (2011), "Product Service Systems and supply network relationships: An exploratory case study", Journal of Manufacturing Technology Management, 22(3), pp. 293-313.

Lüdeke-Freund, F., Gold, S. and Bocken, N.M.P. (2018), “A Review and Typology of Circular Economy Business Model Patterns", Journal of Industrial Ecology, Forthcoming.

Manninen, K., Koskela, S., Antikainen, R., Bocken, N., Dahlbo, H. and Aminoff, A. (2018), "Do circular economy business models capture intended environmental value propositions?", Journal of Cleaner Production, 171, pp. 413-422.

Masi, D., Day, S. and Godsell, J. (2017), "Supply Chain Configurations in the Circular Economy: A Systematic Literature Review”, Sustainability, 9(9), p. 1602.

Masi, D., Kumar, V., Garza-Reyes, J.A. and Godsell, J. (2018), “Towards a more circular economy: exploring the awareness, practices, and barriers from a focal firm perspective", Production Planning and Control, 29(6), pp. 539-550. 
Mont, O., Dalhammar, C. and Jacobsson, N. (2006), "A new business model for baby prams based on leasing and product remanufacturing”, Journal of Cleaner Production, 14(17), pp. 1509-1518.

Ng, I.C.L., Maull, R. and Yip, N. (2009), "Outcome-based contracts as a driver for systems thinking and service-dominant logic in service science: Evidence from the defence industry", European Management Journal, 27(6), pp. 377-387.

Nuñez-Cacho, P., Górecki, J., Molina-Moreno, V. and Corpas-Iglesias, F.A. (2018), "What gets measured, gets done: Development of a Circular Economy measurement scale for building industry", Sustainability (Switzerland), 10(7), p. 2340.

Oghazi, P. and Mostaghel, R. (2018), "Circular business model challenges and lessons learned-An industrial perspective", Sustainability (Switzerland), 10(3), p. 739.

Oliva, R. and Kallenberg, R. (2003), "Managing the transition from products to services", International Journal of Service Industry Management, 14(2), pp. 160-172.

Pal, R. (2016), "Extended responsibility through servitization in PSS", Journal of Fashion Marketing and Management: An International Journal, 20(4), pp. 453-470.

Perey, R., Benn, S., Agarwal, R. and Edwards, M. (2018), “The place of waste: Changing business value for the circular economy", Business Strategy and the Environment, 27(5), pp. 631-642.

Pilbeam, C., Alvarez, G., Wilson, H., Pilbeam, C., Alvarez, G. and Wilson, H. (2012), “The governance of supply networks : a systematic literature review”, Supply Chain Management: An International Journal, 17(4), pp. 358-376.

Piotrowicz, W. and Cuthbertson, R. (2009), "Sustainability - a new dimension in information systems evaluation", Journal of Enterprise Information Management, 22(5), pp. 492-503.

Pittaway, L., Robertson, M., Munir, K., Denyer, D. and Neely, A. (2004), "Networking and innovation: a systematic review of the evidence", International Journal of Management Reviews, 56(3-4), pp. 137-168.

Rabetino, R., Kohtamäki, M., Lehtonen, H. and Kostama, H. (2015), "Developing the concept of lifecycle service offering", Industrial Marketing Management, 49, pp. 53-66.

Reike, D., Vermeulen, W.J.V. and Witjes, S. (2018), “The circular economy: New or Refurbished as CE 3.0? - Exploring Controversies in the Conceptualization of the Circular Economy through a Focus on History and Resource Value Retention Options", Resources, Conservation and Recycling, 135(February 2017), pp. 246-264.

Reim, W., Parida, V. and Örtqvist, D. (2015), "Product-Service Systems (PSS) business models and tactics - A systematic literature review”, Journal of Cleaner Production, 97, pp. 61-75.

Reim, W., Parida, V. and Sjödin, D.R. (2016), "Risk management for product-service system 
Running Head: Effect of servitisation on supply chain circularity

operation", International Journal of Operations \& Production Management, 36(6), pp. 665-686.

Rizos, V., Behrens, A., van der Gaast, W., Hofman, E., Ioannou, A., Kafyeke, T., Flamos, A., Rinaldi, R., Papadelis, S., Hirschnitz-Garbers, M. and Topi, C. (2016), "Implementation of circular economy business models by small and medium-sized enterprises (SMEs): Barriers and enablers", Sustainability (Switzerland), 8(11), p. 1212.

Roh, J.J., Hong, P. and Park, Y. (2008), “Organizational culture and supply chain strategy: A framework for effective information flows", Journal of Enterprise Information Management, 21(4), pp. 361-376.

Rousseau, D.M., Manning, J. and Denyer, D. (2008), “Evidence in Management and Organizational Science: Assembling the Field's Full Weight of Scientific Knowledge Through Syntheses", The Academy of Management Annals, 2(1), pp. 475-515.

Saccani, N., Visintin, F. and Rapaccini, M. (2014), "Investigating the linkages between service types and supplier relationships in servitized environments", International Journal of Production Economics, 149, pp. 226-238.

Sambasivan, M., Nandan, T. and Mohamed, Z.A. (2009), "Consolidation of performance measures in a supply chain environment”, Journal of Enterprise Information Management, 22(6), pp.660-689.

Settanni, E., Thenent, N.E., Newnes, L.B., Parry, G. and Goh, Y.M. (2017), “Mapping a productservice-system delivering defence avionics availability", International Journal of Production Economics, 186(September 2014), pp. 21-32.

Seuring, S. and Müller, M. (2008), "From a literature review to a conceptual framework for sustainable supply chain management”, Journal of Cleaner Production, 16(15), pp. 1699-1710.

Smith, L., Maull, R. and Ng, I.C.L. (2014), “Servitization and operations management: a service dominant-logic approach", International Journal of Operations \& Production Management, 34(2), pp. 242-269.

Sousa-Zomer, T.T., Magalhães, L., Zancul, E., Campos, L.M.S. and Cauchick-Miguel, P.A. (2018a), "Cleaner production as an antecedent for circular economy paradigm shift at the micro-level: Evidence from a home appliance manufacturer", Journal of Cleaner Production, 185, pp. 740-748.

Sousa-Zomer, T.T., Magalhães, L., Zancul, E. and Cauchick-Miguel, P.A. (2018b), "Exploring the challenges for circular business implementation in manufacturing companies: An empirical investigation of a pay-per-use service provider", Resources, Conservation and Recycling, 135(August 2017), pp. 3-13.

Spring, M. and Araujo, L. (2017), "Product biographies in servitization and the circular economy", Industrial Marketing Management, 60, pp. 126-137. 
Story, V.M., Raddats, C., Burton, J., Zolkiewski, J. and Baines, T. (2017), “Capabilities for advanced services: A multi-actor perspective", Industrial Marketing Management, 60, pp. 54-68.

Strandberg, C. (2017), "HP and the Circular Economy", available at:

http://www8.hp.com/h20195/v2/getpdf.aspx/c05364027.pdf (accessed 9 January 2019).

Sundin, E. and Bras, B. (2005), "Making functional sales environmentally and economically beneficial through product remanufacturing", Journal of Cleaner Production, 13(9), pp. 913-925.

Sundin, E., Lindahl, M. and Ijomah, W. (2009), "Product design for product/service systems: Design experiences from Swedish industry", Journal of Manufacturing Technology Management, 20(5), pp. $723-753$.

Tranfield, D., Denyer, D. and Smart, P. (2003), “Towards a methodology for developing evidenceinformed management knowledge by means of systematic review", British Journal of Management, 14 , pp. 207-222.

Tukker, A. (2004), “Eight Types of Product-Service System: Eight Ways to Sustainability?”, Business Strategy and the Environment, 260(13), pp. 246-260.

Tukker, A. (2015), "Product services for a resource-efficient and circular economy - a review", Journal of Cleaner Production, 97, pp. 76-91.

Vandermerwe, S. and Rada, J. (1988), "Servitization of Business : Adding Value by Adding Services", European Management Journal, 6(4), pp. 314-324.

Vezzoli, C., Ceschin, F., Diehl, J.C. and Kohtala, C. (2015), "New design challenges to widely implement 'Sustainable Product-Service Systems"”, Journal of Cleaner Production, 97, pp. 1-12. Walters, D. and Rainbird, M. (2007), “Cooperative innovation: A value chain approach”, Journal of Enterprise Information Management, 20(5), pp. 595-607.

Wise, R. and Baumgartner, P. (1999), “Go Downstream: The New Profit Imperative in Manufacturing.”, Harvard Business Review, 77(5), pp. 133-141.

Yang, M., Smart, P., Kumar, M., Jolly, M. and Evans, S. (2018), "Product-service system business models for circular supply chains”, Production Planning and Control, 29(6), pp. 498-508. 
Running Head: Effect of servitisation on supply chain circularity

Table 1 - Search strings

\begin{tabular}{|c|c|c|}
\hline $\begin{array}{l}\text { SS1: Supply } \\
\text { Chain } \\
\text { Management }\end{array}$ & $\begin{array}{l}\text { SS2: Circular } \\
\text { Economy }\end{array}$ & SS3: Product-service systems \\
\hline $\begin{array}{l}\text { Supply Chain* } \\
\text { Value Chain* } \\
\text { Demand Chain* } \\
\text { Logistics } \\
\text { Supply Network* } \\
\text { Value Network* } \\
\text { Operations* }\end{array}$ & Circular Economy & $\begin{array}{l}\text { Product?service?system } \\
\text { PSS } \\
\text { Serviti?ation } \\
\text { Outcome?based } \\
\text { Advanced services } \\
\text { Industrial service } \\
\text { Hybrid solution } \\
\text { Functional sales } \\
\text { Performance?based }\end{array}$ \\
\hline
\end{tabular}


Running Head: Effect of servitisation on supply chain circularity

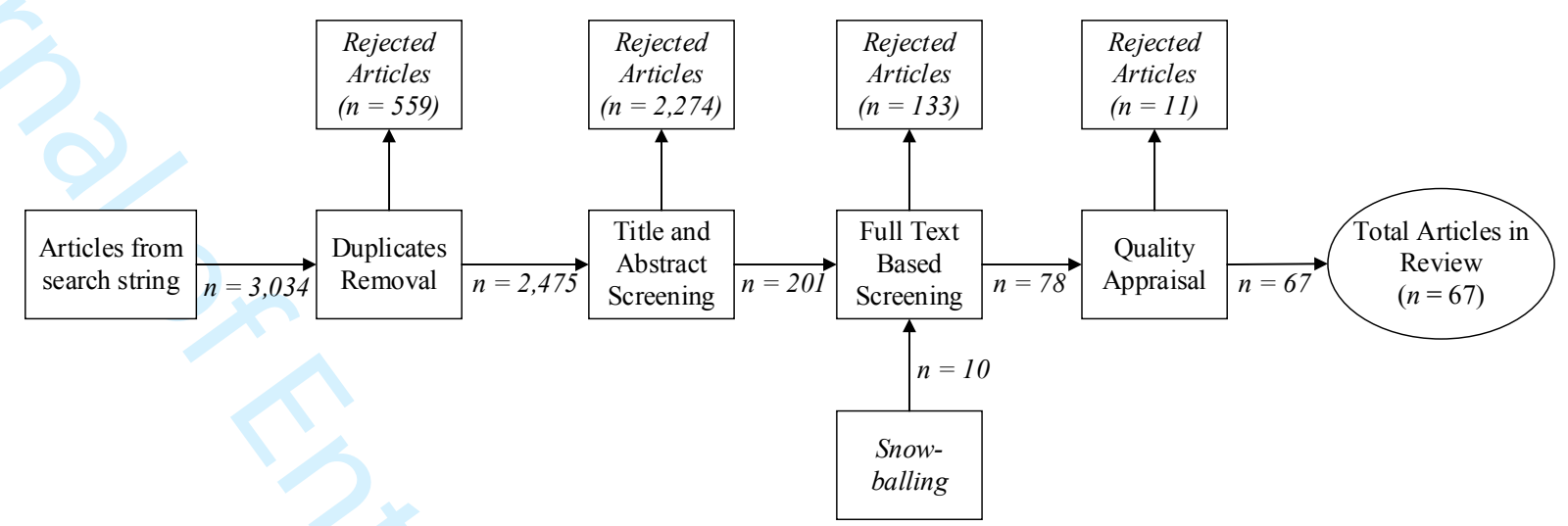

Figure 1 - Paper search and selection process 
Running Head: Effect of servitisation on supply chain circularity

Table 2 - Criteria for including papers in the review

\section{Criteria}

Published in peer-reviewed journals

Studies that are written in English

Open to any time frame

Open to any geography

Theoretical, empirical studies and review papers, either qualitative or quantitative

Focused on ('supply chain management' AND 'circular economy') OR ('supply chain management' AND 'product-service systems') OR ('supply chain management' AND 'circular economy' AND 'product-service systems')

\section{Rationale}

Peer-reviewed journal articles are likely to have a higher quality than non-peer reviewed publications, such as conference papers or reports.

Language skills of the authors.

The field developed significantly since the 1980 s, but some seminal papers predate this.

Contributions to the research area stem from around the world.

Different methodological approaches contribute to the research domain.

Different search string combinations are required to answer the review questions. 
Running heads: Effect of servitisation on supply chain circularity

Distribution of Publications

25

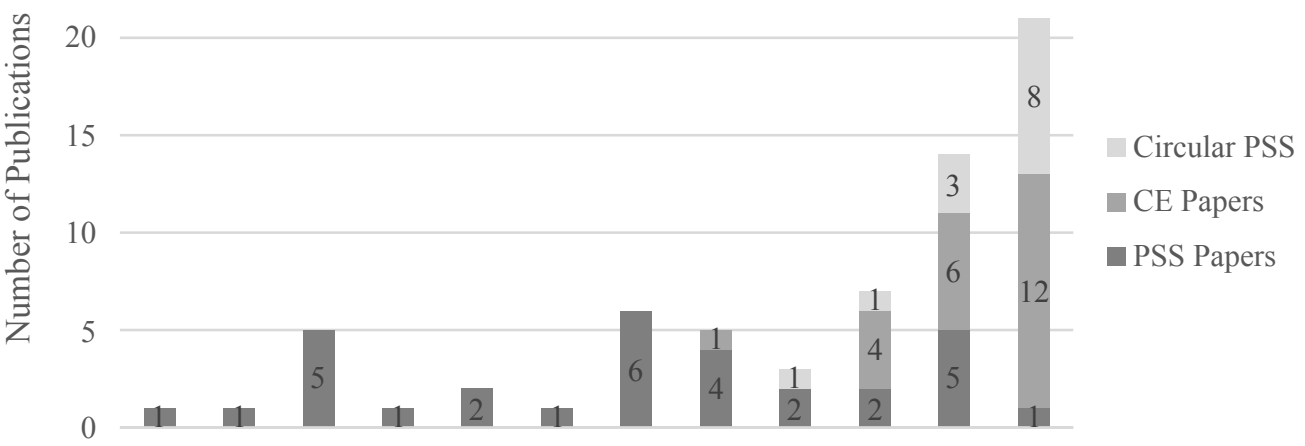

200520082009201020112012201320142015201620172018

Year of Publication

Figure 2 - Distribution of publications 
Running Head: Effect of servitisation on supply chain circularity

Table 3 - Descriptive analysis of the literature review

\begin{tabular}{|c|c|c|}
\hline Descriptive Category & Sub-Category & Number of Papers \\
\hline \multirow[t]{7}{*}{ Research Methodology } & Non-Empirical & \\
\hline & Conceptual & 8 \\
\hline & Literature Review & 12 \\
\hline & Mathematical & 1 \\
\hline & Empirical & \\
\hline & Case studies & 42 \\
\hline & Survey & 4 \\
\hline \multirow[t]{7}{*}{ Geographic Context* } & None & 21 \\
\hline & Asia & 2 \\
\hline & Australia & 1 \\
\hline & Europe & 40 \\
\hline & North America & 1 \\
\hline & South America & 3 \\
\hline & Worldwide & 1 \\
\hline \multirow[t]{13}{*}{ Industry setting* } & Aerospace & 2 \\
\hline & Automotive & 3 \\
\hline & Bicycles & 2 \\
\hline & Capital equipment & 14 \\
\hline & Chemical/food & 1 \\
\hline & Construction equipment & 4 \\
\hline & Defence & 6 \\
\hline & Household appliances & 6 \\
\hline & Material handling equipment & 3 \\
\hline & Medical equipment & 3 \\
\hline & Office equipment & 1 \\
\hline & Textiles & 3 \\
\hline & Transportation equipment & 3 \\
\hline \multirow[t]{3}{*}{ PSS Type* } & Product-Oriented & 14 \\
\hline & Use-Oriented & 12 \\
\hline & Result-Oriented & 24 \\
\hline \multirow[t]{7}{*}{ Journal** } & Journal of Cleaner Production & 15 \\
\hline & International Journal of Operations \& Production & 9 \\
\hline & Management & \\
\hline & International Journal of Production Economics & 5 \\
\hline & Industrial Marketing Management & 5 \\
\hline & Production Planning \& Control & 5 \\
\hline & Sustainability & 5 \\
\hline
\end{tabular}

* May vary since some papers employed multiple case studies.

**Includes top six most frequently included journals 
Running Head: Effect of servitisation on supply chain circularity

Table 4-SCC principal aims, practices and performance measures

\begin{tabular}{|c|c|c|c|}
\hline Aim & Associated Practices & Performance Measure & $\begin{array}{l}\text { Performance Measure } \\
\text { Source }\end{array}$ \\
\hline $\begin{array}{l}\text { Close } \\
\text { resource } \\
\text { loops }\end{array}$ & $\begin{array}{l}\text { Source secondary materials; } \\
\text { Cascading; Recycling; } \\
\text { Remanufacturing }\end{array}$ & $\begin{array}{r}\text { Circularity }=(\text { economic value of recirculated parts }) / \\
\text { (economic value of all parts) }\end{array}$ & (Linder et al., 2017) \\
\hline $\begin{array}{l}\text { Increase } \\
\text { product } \\
\text { longevity }\end{array}$ & $\begin{array}{l}\text { Design for disassembly; } \\
\text { Design for longevity; } \\
\text { Design for modularity; } \\
\text { Reuse/Resell; Maintenance } \\
\text { and Repair; Refurbish }\end{array}$ & $\begin{array}{l}\text { Longevity }=\mathrm{A}+\mathrm{B}+\mathrm{C} \\
\mathrm{A} \text { is initial life time of the product; } \mathrm{B} \text { is refurbished } \\
\text { lifetime contribution; } \mathrm{C} \text { is recycled lifetime } \\
\text { contribution. }\end{array}$ & $\begin{array}{l}\text { (Franklin-Johnson et al., } \\
\text { 2016) }\end{array}$ \\
\hline $\begin{array}{l}\text { Increase } \\
\text { resource } \\
\text { efficiency }\end{array}$ & $\begin{array}{l}\text { Source secondary materials; } \\
\text { Customisation; Reduce } \\
\text { resource use; Eco-efficient } \\
\text { production processes / } \\
\text { technology; Sustainable } \\
\text { design of distribution } \\
\text { system; Operational } \\
\text { efficiency }\end{array}$ & $\begin{array}{l}\text { Decreasing emissions (e.g. GHG emissions; Air) } \\
\text { Decreasing energy consumption (e.g. Energy } \\
\text { consumption; use of renewable energy sources) } \\
\text { Decreasing waste (e.g. solid; liquid/water; } \\
\text { hazardous/harmful/toxic) }\end{array}$ & $\begin{array}{l}\text { (Genovese } \text { et al., 2017; } \\
\text { Kazancoglu et al., 2018; } \\
\text { Nuñez-Cacho et al., 2018; } \\
\text { Sousa-Zomer } \text { et al., 2018a) }\end{array}$ \\
\hline
\end{tabular}


Table 5 - Circular supply chain practices related to the principal aims

\begin{tabular}{|c|c|c|c|c|}
\hline $\begin{array}{l}\text { Supply Chain } \\
\text { Process }\end{array}$ & Practice & Aim & Practice Description & Practice Source \\
\hline $\begin{array}{l}\text { Material } \\
\text { Sourcing }\end{array}$ & $\begin{array}{l}\text { Source } \\
\text { secondary } \\
\text { materials }\end{array}$ & $\begin{array}{l}\text { Closed } \\
\text { resource } \\
\text { loops }\end{array}$ & $\begin{array}{l}\text { Replace materials with more abundant secondary } \\
\text { materials or renewable ones. }\end{array}$ & $\begin{array}{l}\text { (De Angelis et al., 2018; Batista et al., 2018; Franco, 2017; Genovese et al., 2017; Kalmykova et al., } \\
\text { 2018; Kazancoglu et al., 2018; Masi et al., 2018; Perey et al., 2018; Spring and Araujo, 2017) }\end{array}$ \\
\hline \multirow[t]{5}{*}{ Design } & Customisation & $\begin{array}{l}\text { Resource } \\
\text { efficiency }\end{array}$ & $\begin{array}{l}\text { Products are bespoke and meet the needs and } \\
\text { preferences of the customer. This can help reduce } \\
\text { waste and prevent over-production. }\end{array}$ & (Kalmykova et al., 2018) \\
\hline & $\begin{array}{l}\text { Design for } \\
\text { disassembly }\end{array}$ & $\begin{array}{l}\text { Product } \\
\text { longevity }\end{array}$ & $\begin{array}{l}\text { Design products in a way that considers disassembly } \\
\text { for repair, remanufacturing, recycling. }\end{array}$ & $\begin{array}{l}\text { (De Angelis et al., 2018; Elia et al., 2017; Ghisellini et al., 2016; Govindan et al., 2018; Kalmykova et } \\
\text { al., 2018; Kazancoglu et al., 2018; Lieder and Rashid, 2016; Masi et al., 2018) }\end{array}$ \\
\hline & $\begin{array}{l}\text { Design for } \\
\text { longevity }\end{array}$ & $\begin{array}{l}\text { Product } \\
\text { longevity }\end{array}$ & $\begin{array}{l}\text { Design products to last longer, considering the } \\
\text { physical and emotional durability. }\end{array}$ & $\begin{array}{l}\text { (De Angelis et al., 2018; Franklin-Johnson et al., 2016; Ghisellini et al., 2016; Kazancoglu et al., 2018; } \\
\text { Kjaer et al., 2018; Lieder and Rashid, 2016; Lüdeke-Freund } \text { et al., 2018; Manninen et al., 2018; Spring } \\
\text { and Araujo, 2017) }\end{array}$ \\
\hline & $\begin{array}{l}\text { Design for } \\
\text { modularity }\end{array}$ & $\begin{array}{l}\text { Product } \\
\text { longevity }\end{array}$ & $\begin{array}{l}\text { Products are designed to include functional modules } \\
\text { so that they can be more easily serviced, repaired or } \\
\text { replaced, also upgraded. }\end{array}$ & $\begin{array}{l}\text { (Kalmykova et al., 2018; Lieder and Rashid, 2016; Lüdeke-Freund et al., 2018; Spring and Araujo, } \\
\text { 2017) }\end{array}$ \\
\hline & $\begin{array}{l}\text { Reduce resource } \\
\text { use }\end{array}$ & $\begin{array}{l}\text { Resource } \\
\text { efficiency }\end{array}$ & $\begin{array}{l}\text { Design that minimises the amount of materials used, } \\
\text { especially toxic or hazardous substances. }\end{array}$ & (Kjaer et al., 2018; Lieder and Rashid, 2016; Masi et al., 2018; Reike et al. 2018) \\
\hline Production & $\begin{array}{l}\text { Eco-efficient } \\
\text { production } \\
\text { processes/ } \\
\text { technology }\end{array}$ & $\begin{array}{l}\text { Resource } \\
\text { efficiency }\end{array}$ & $\begin{array}{l}\text { Manufacturing processes and technology are } \\
\text { designed to maximise energy efficiency / minimise } \\
\text { waste / minimise water \& energy consumption. Use } \\
\text { renewable energy sources. }\end{array}$ & $\begin{array}{l}\text { (Elia et al. 2017; Kalmykova et al., 2018; Kazancoglu et al., 2018; Masi et al., 2018; Reike et al., } \\
\text { 2018; Sousa-Zomer } \text { et al., 2018a) }\end{array}$ \\
\hline \multirow[t]{2}{*}{ Distribution } & Reuse/ Resell & $\begin{array}{l}\text { Product } \\
\text { longevity }\end{array}$ & $\begin{array}{l}\text { Resell products, components for same purpose, } \\
\text { second-hand. }\end{array}$ & $\begin{array}{l}\text { (De Angelis et al., 2018; Batista et al., 2018; Govindan and Hasanagic, 2018; Kalmykova et al., 2018; } \\
\text { Kazancoglu et al., 2018; Kirchherr et al., 2017; Kjaer et al., 2018; Lieder and Rashid, 2016; Linder et } \\
\text { al., 2017; Lüdeke-Freund et al., 2018; Manninen et al., 2018; Masi et al., 2018; Reike et al., 2018) }\end{array}$ \\
\hline & $\begin{array}{l}\text { Sustainable } \\
\text { design of } \\
\text { distribution } \\
\text { system }\end{array}$ & $\begin{array}{l}\text { Resource } \\
\text { efficiency }\end{array}$ & $\begin{array}{l}\text { Includes switching to more sustainable modes of } \\
\text { transportation, route optimisation or eco-driving. } \\
\text { Design packaging material to reduce overall } \\
\text { resource use. }\end{array}$ & (Kalmykova et al., 2018; Kazancoglu et al., 2018; Sousa-Zomer et al., 2018a) \\
\hline \multirow[t]{3}{*}{ Use } & $\begin{array}{l}\text { Maintenance and } \\
\text { Repairs }\end{array}$ & $\begin{array}{l}\text { Product } \\
\text { longevity }\end{array}$ & $\begin{array}{l}\text { Conduct maintenance, repair activities or product } \\
\text { upgrades. The purpose is to extend the product } \\
\text { lifetime. }\end{array}$ & $\begin{array}{l}\text { (De Angelis et al., 2018; Batista et al., 2018; Bressanelli et al., 2018; Geissdoerfer et al., 2018; } \\
\text { Kalmykova et al., 2018; Kirchherr et al., 2017; Kjaer et al., 2018; Lüdeke-Freund et al., 2018; Reike et } \\
\text { al., 2018) }\end{array}$ \\
\hline & $\begin{array}{l}\text { Operational } \\
\text { efficiency }\end{array}$ & $\begin{array}{l}\text { Resource } \\
\text { efficiency }\end{array}$ & $\begin{array}{l}\text { Decreasing emissions, resource consumption, waste } \\
\text { during use phase }\end{array}$ & (Kalmykova et al., 2018; Kazancoglu et al., 2018; Kjaer et al., 2018; Reike et al., 2018) \\
\hline & Refurbish & $\begin{array}{l}\text { Product } \\
\text { longevity }\end{array}$ & $\begin{array}{l}\text { Overall structure of a complex product remains } \\
\text { more or less intact, while a number of components }\end{array}$ & $\begin{array}{l}\text { (De Angelis et al., 2018; Franklin-Johnson et al., 2016; Govindan and Hasanagic, 2018; Kalmykova et } \\
\text { al., 2018; Kirchherr } \text { et al., 2017; Kjaer } \text { et al., 2018; Lüdeke-Freund et al., 2018; Masi et al., 2018; } \\
\text { Reike et al., 2018) }\end{array}$ \\
\hline
\end{tabular}


Running Head: Effect of servitisation on supply chain circularity

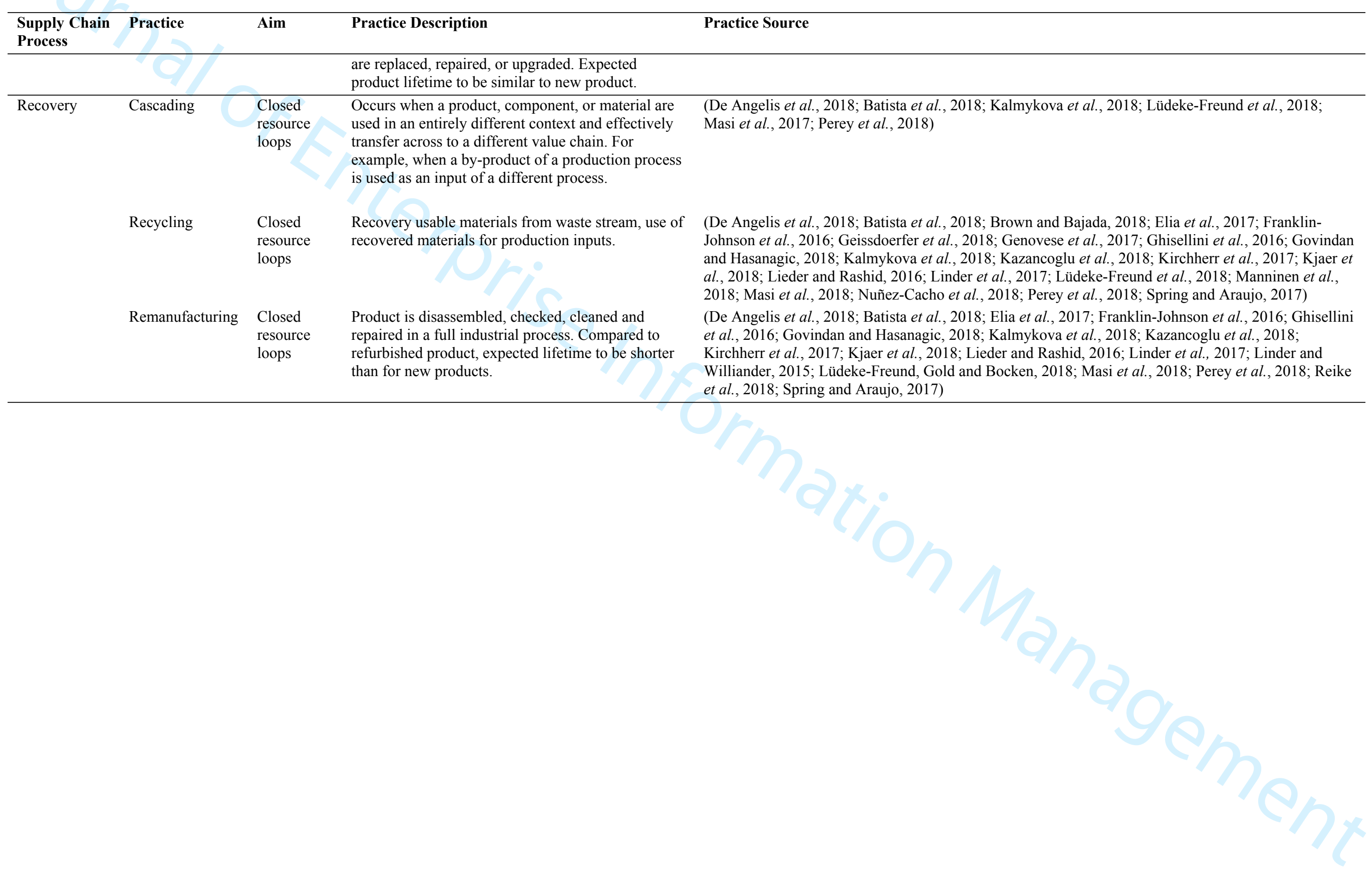


Table 6 - Evidence of supply chain circularity practices in empirical PSS papers

\begin{tabular}{|c|c|c|c|c|c|c|c|c|c|c|c|c|c|c|c|c|c|c|}
\hline \multirow[t]{4}{*}{ PSS } & \multirow[t]{4}{*}{ Source } & \multirow[t]{4}{*}{ Industry } & \multirow{4}{*}{$\begin{array}{l}\text { Geographic } \\
\text { context }\end{array}$} & \multicolumn{15}{|c|}{ SCC Practices } \\
\hline & & & & 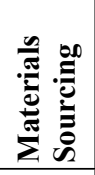 & 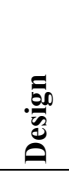 & & & & & 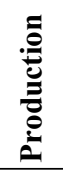 & 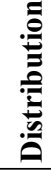 & & $\ddot{\mathscr{D}}$ & & & 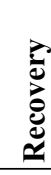 & & \\
\hline & & & & $*$ & $* * *$ & $* *$ & $* *$ & $* *$ & $* * *$ & $* * *$ & $* *$ & $* * *$ & $* *$ & $* * *$ & $* *$ & $*$ & $*$ & $*$ \\
\hline & & & & 1 & 2 & 3 & 4 & 5 & 6 & 7 & 8 & 9 & 10 & 11 & 12 & 13 & 14 & 15 \\
\hline \multirow{14}{*}{ 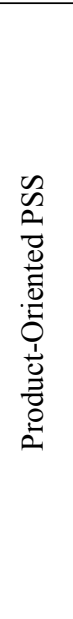 } & Baines et al. (2009b) & Capital equipment & Europe & & & & & & & & & & $x$ & & $x$ & & & \\
\hline & Bastl et al. (2012) & Capital equipment & Europe & & & & & & & & & & $x$ & & $x$ & & & \\
\hline & Chakkol et al. (2014) & Automotive & Europe & & & & & & & & & & $x$ & $x$ & & & & \\
\hline & Colen and Lambrecht (2013) & Capital equipment & Europe & & & & $x$ & & & & & & $x$ & & & & & $x$ \\
\hline & Corvellec and Stål (2017) & Textiles & Europe & & & & & & & & $x$ & & $x$ & & & & $x$ & \\
\hline & Durugbo (2013) & Capital equipment & Europe & & & & & & & & & & $x$ & & & & & \\
\hline & Finne and Holmström (2013) & Capital equipment & Europe & & & & & & & & & & $x$ & & $x$ & & & \\
\hline & Gebauer et al. (2013) & Capital equipment & Europe & & & & & & & & & & $x$ & & $x$ & & & \\
\hline & Lockett et al. (2011) & Capital equipment & Europe & & & & & & & & & & $x$ & & & & & \\
\hline & $\mathrm{Pal}(2016)$ & Textiles & Europe & & & & & & & & & & $x$ & & & & $x$ & \\
\hline & Reim et al. (2016) & Construction equipment & Europe & & & & & & & & & & $x$ & & & & & \\
\hline & Smith et al. (2014) & Capital equipment & Europe & & & & & & & & & & $x$ & & & & & \\
\hline & Sundin et al. (2009) & Construction equipment & Europe & & & & & & & & & & $x$ & & & & & $x$ \\
\hline & Yang et al. (2018) & Capital equipment & Asia & & & & & & & & & & $x$ & & & & & \\
\hline \multirow{11}{*}{ 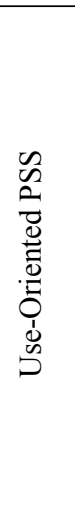 } & Bressanelli et al. (2018) & Household appliances & Europe & & & & & 8 & & & & & $x$ & $x$ & $x$ & & $x$ & $x$ \\
\hline & Corvellec and Stål (2017) & Textiles & Europe & & & & & & & & $x$ & & & & & & $x$ & \\
\hline & Fargnoli et al. (2018) & Medical equipment & Europe & & & $x$ & & & & & & & $x$ & & & & & \\
\hline & Geissdoerfer et al. (2018) & Bicycle & S. America & & & & $x$ & & & & & & $x$ & & & & & \\
\hline & Johnson and Mena (2008) & Material handling equipment & Europe & & & & & & & & $x$ & & $x$ & & & & & \\
\hline & Lindahl et al. (2014) & Construction equipment & Europe & & & & $x$ & & & & & & & & & & & $x$ \\
\hline & Linder and Williander (2015) & Bicycle & Europe & & & & & & & & & & $x$ & & & & & $x$ \\
\hline & $\mathrm{Pal}(2016)$ & Textiles & Europe & & & & & & & & & & $x$ & & & & & \\
\hline & $\begin{array}{l}\text { Sousa-Zomer et al. (2018a, } \\
2018 \mathrm{~b})\end{array}$ & Household appliances & S. America & $x$ & & $x$ & $x$ & & & $x$ & $x$ & $x$ & $x$ & & & $x$ & $x$ & \\
\hline & Sundin and Bras (2005) & Household appliances & Europe & & & & & & & & & & $x$ & & & & & $x$ \\
\hline & Yang et al. (2018) & Capital equipment & Asia & & & & & & & & $x$ & & $x$ & & & & $x$ & $x$ \\
\hline
\end{tabular}




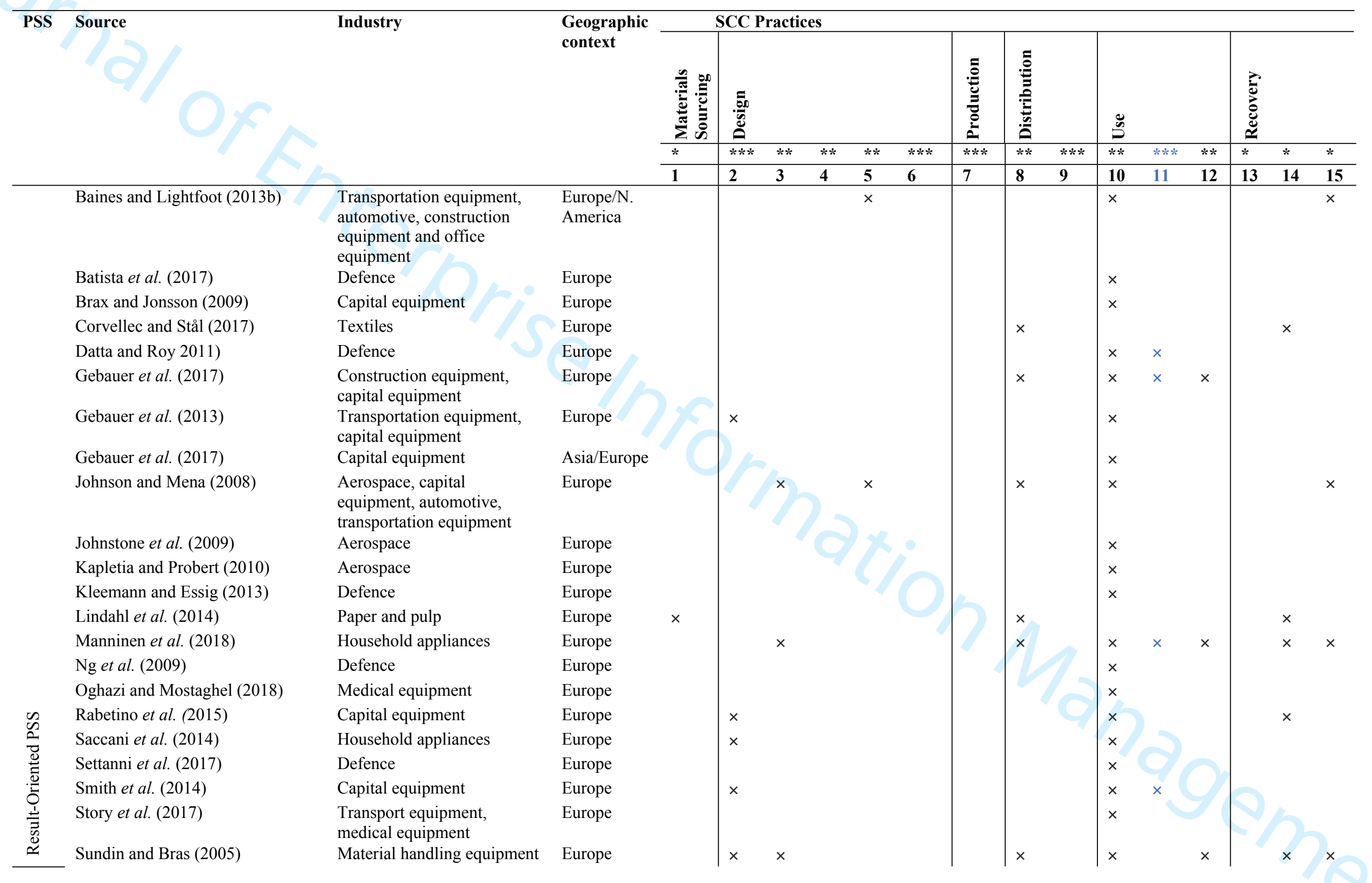


Running Head: Effect of servitisation on supply chain circularity

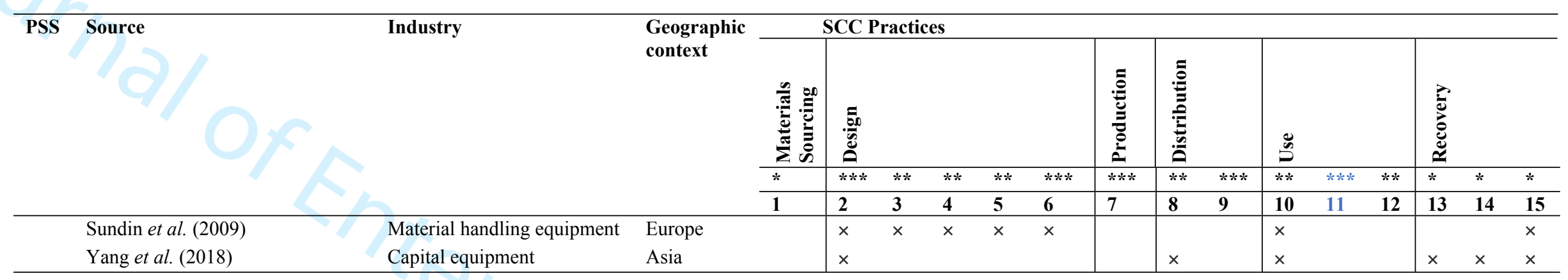

Notes: 1 . In the third row in the header: $*=$ Close resource loops, $* *=$ Increase product longevity, $* * *=$ Increase resource efficiency; 2 . In the fourth row of the header: 1 is Source secondary materials; 2 is Customisation; 3 is Design for disassembly; 4 is Design for longevity; 5 is Design for modularity; 6 is Reduce resource use; 7 is Eco-efficient production processes/ technology; 8 is Reuse/ Resell; 9 is Sustainable design of distribution system; 10 is Maintenance and Repairs; 11 is Operational efficiency; 12 is Refurbish; 13 is Cascading; 14 is Recycling; 15 is Remanufacturing. 
Table 7 - Contextual factors affecting SCC

\begin{tabular}{|c|c|c|c|c|}
\hline Category & $\begin{array}{l}\text { Contextual } \\
\text { Factor }\end{array}$ & Description & Effect on circular supply chain practices & Source \\
\hline \multirow[t]{3}{*}{$\begin{array}{l}\text { Economic } \\
\text { attractiveness } \\
\text { of SCC }\end{array}$} & Cost impact & $\begin{array}{l}\text { Additional costs for implementing } \\
\text { circular supply chain practices. }\end{array}$ & $\begin{array}{l}\text { Negative }- \text { by increasing operational, planning, } \\
\text { and/or sourcing costs. } \\
\text { Positive - by reducing maintenance and/or after-sale } \\
\text { service costs. }\end{array}$ & $\begin{array}{l}\text { (Colen and Lambrecht, 2013; Franco, 2017; Govindan and Hasanagic, } \\
\text { 2018; Lieder and Rashid, 2016; Linder and Williander, 2015; Masi et al., } \\
\text { 2017; Masi et al., 2018; Oghazi and Mostaghel, 2018; Rizos et al., 2016; } \\
\text { Sundin et al., 2009; Yang et al., 2018) }\end{array}$ \\
\hline & $\begin{array}{l}\text { Growth } \\
\text { opportunities }\end{array}$ & $\begin{array}{l}\text { Economic opportunities stemming } \\
\text { from selling products multiple times. }\end{array}$ & Positive - by creating new revenue sources. & (Gebauer et al., 2017; Reim et al., 2015; Sundin et al., 2009) \\
\hline & $\begin{array}{l}\text { Risk of } \\
\text { cannibalisation }\end{array}$ & $\begin{array}{l}\text { Risk that circular practices may } \\
\text { reduce product sales. }\end{array}$ & Negative - by threatening sales. & (Linder and Williander, 2015; Lockett et al., 2011) \\
\hline $\begin{array}{l}\text { Firm } \\
\text { sustainability } \\
\text { strategy }\end{array}$ & $\begin{array}{l}\text { Firm } \\
\text { sustainability } \\
\text { strategy }\end{array}$ & $\begin{array}{l}\text { Firm internal sustainability strategy } \\
\text { and circular economy policy. }\end{array}$ & $\begin{array}{l}\text { Positive - by increasing the organisational and } \\
\text { individual commitment to circular supply chain } \\
\text { practices. }\end{array}$ & $\begin{array}{l}\text { (Corvellec and Stål, 2017; Geissdoerfer et al., 2018; Masi et al., 2017; } \\
\text { Perey et al., 2018; Rizos et al., 2016; Sousa-Zomer } \text { et al., 2018b) }\end{array}$ \\
\hline \multirow[t]{4}{*}{$\begin{array}{l}\text { Policy and } \\
\text { societal } \\
\text { environment }\end{array}$} & $\begin{array}{l}\text { Customer } \\
\text { acceptance }\end{array}$ & $\begin{array}{l}\text { Customer acceptance of innovative } \\
\text { business models and/or } \\
\text { refurbished/remanufactured } \\
\text { products. }\end{array}$ & $\begin{array}{l}\text { Negative - due to customer perception that } \\
\text { refurbished/remanufactured products have inferior } \\
\text { quality. }\end{array}$ & (Govindan and Hasanagic, 2018; Lieder and Rashid, 2016) \\
\hline & $\begin{array}{l}\text { Laws and } \\
\text { regulations }\end{array}$ & $\begin{array}{l}\text { Relevant existing laws and } \\
\text { regulations. }\end{array}$ & $\begin{array}{l}\text { Negative - by preventing waste recovery; stifling } \\
\text { collaboration through competition laws. }\end{array}$ & $\begin{array}{l}\text { (De Angelis et al., 2018; Brown and Bajada, 2018; Fargnoli et al., 2018; } \\
\text { Franco, 2017; Genovese et al., 2017; Lieder and Rashid, 2016; Linder and }\end{array}$ \\
\hline & & & $\begin{array}{l}\text { Positive - by supporting practices, for example, } \\
\text { through tax benefits and/or recycling requirements. }\end{array}$ & Williander, 2015; Masi, Day and Godsell, 2017) \\
\hline & $\begin{array}{l}\text { Waste } \\
\text { management } \\
\text { infrastructure }\end{array}$ & $\begin{array}{l}\text { Existing infrastructure for collection } \\
\text { and processing of wastes. }\end{array}$ & $\begin{array}{l}\text { Positive - by providing the necessary infrastructure to } \\
\text { implement collection, recovery activities. }\end{array}$ & (Corvellec and Stål, 2017) \\
\hline \multirow[t]{2}{*}{$\begin{array}{l}\text { Product } \\
\text { category }\end{array}$} & $\begin{array}{l}\text { Product } \\
\text { characteristics }\end{array}$ & $\begin{array}{l}\text { Includes product lifetime, } \\
\text { complexity of product designs, as }\end{array}$ & $\begin{array}{l}\text { Positive - by having stable technology; a core that } \\
\text { can be reused; low deterioration of economic value. }\end{array}$ & $\begin{array}{l}\text { (Franco, 2017; Ghisellini et al., 2016; Linder and Williander, 2015; } \\
\text { Andreu, cited in Sundin et al., 2009) }\end{array}$ \\
\hline & & $\begin{array}{l}\text { well as functional, economic and } \\
\text { aesthetic deterioration over time. }\end{array}$ & $\begin{array}{l}\text { Negative - by limiting recovery options (e.g. material } \\
\text { restrictions); being subject to fashion changes. }\end{array}$ & \\
\hline \multirow[t]{2}{*}{$\begin{array}{l}\text { Supply chain } \\
\text { relationships }\end{array}$} & $\begin{array}{l}\text { Cross-sector } \\
\text { supply chain } \\
\text { collaboration }\end{array}$ & $\begin{array}{l}\text { Actors engage in collaboration with } \\
\text { actors outside their supply chain to } \\
\text { prevent impacts, resources from } \\
\text { becoming wastes. }\end{array}$ & $\begin{array}{l}\text { Positive - by enabling the development of cascading } \\
\text { resource flows. }\end{array}$ & $\begin{array}{l}\text { (De Angelis et al., 2018; Batista } \text { et al., 2018; Bernon et al., 2018; Brown } \\
\text { and Bajada, 2018; Elia et al., 2017; Koh et al., 2017; Perey et al., 2018; } \\
\text { Yang et al., 2018) }\end{array}$ \\
\hline & $\begin{array}{l}\text { Supply chain } \\
\text { integration }\end{array}$ & $\begin{array}{l}\text { Degree to which intra- and inter- } \\
\text { organisational processes are } \\
\text { managed collaboratively. }\end{array}$ & $\begin{array}{l}\text { Positive - by facilitating information sharing and } \\
\text { alignment of actors towards desired outcomes. }\end{array}$ & $\begin{array}{l}\text { (Baines and Lightfoot, 2013b; Batista } \text { et al., 2017; Bernon et al., 2018; } \\
\text { Chakkol et al., 2014; Fargnoli et al., 2018; Finne and Holmström, 2013; } \\
\text { Kleemann and Essig, 2013; Liu et al., 2014; Lockett et al., 2011; Saccani }\end{array}$ \\
\hline
\end{tabular}


Running Head: Effect of servitisation on supply chain circularity

\begin{tabular}{|c|c|c|c|c|}
\hline & 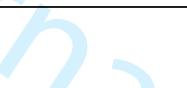 & & & $\begin{array}{l}\text { et al., 2014; Smith et al., 2014; Sousa-Zomer et al., 2018b; Spring and } \\
\text { Araujo, 2017) }\end{array}$ \\
\hline Technology & $\begin{array}{l}\text { Digital } \\
\text { technologies }\end{array}$ & $\begin{array}{l}\text { Digital technologies around the } \\
\text { internet of things, big data, tracking } \\
\text { and monitoring. }\end{array}$ & $\begin{array}{l}\text { Positive - by providing information on asset use, } \\
\text { condition, and location; facilitating maintenance, } \\
\text { repair activities; providing information to improve } \\
\text { product design; facilitating recovery. }\end{array}$ & $\begin{array}{l}\text { (Baines and Lightfoot, 2013b; Bressanelli et al., 2018; Colen and } \\
\text { Lambrecht, 2013; Lieder and Rashid, 2016; Spring and Araujo, 2017) }\end{array}$ \\
\hline
\end{tabular}


Running Head: Effect of servitisation on supply chain circularity

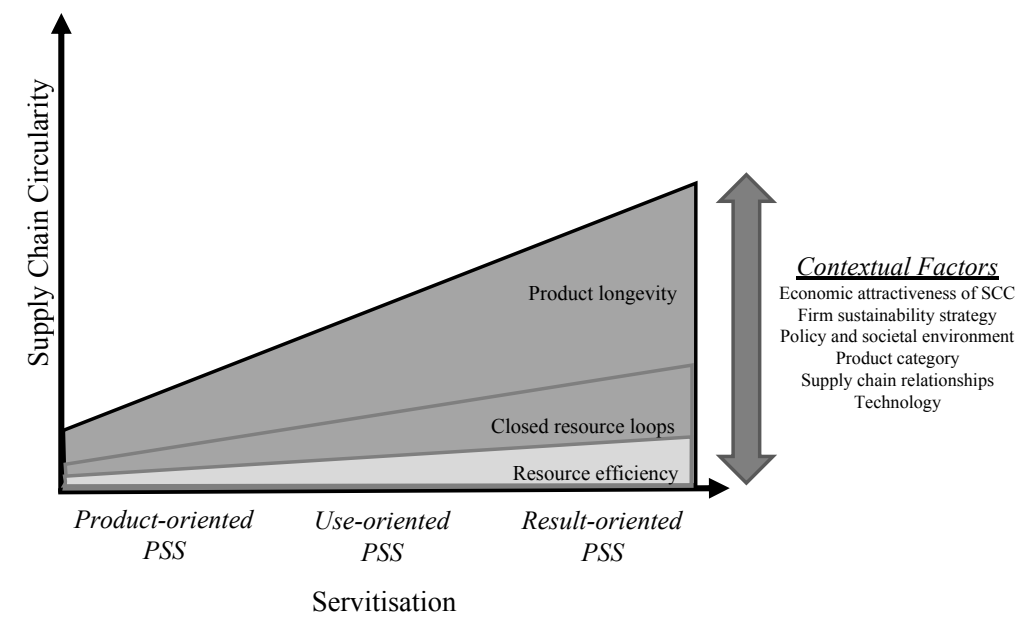

Figure 3 - Conceptual model of the relationship between servitisation and SCC 